\title{
EFFECT OF REINFORCEMENT RICOTTA CHEESE BY SKIM MILK POWDER AND MILK PROTEIN CONCENTRATE POWDER ON THE QUALITY OF THE CHEESE TARGET DURING STORAGE.
}

Gomaa, M. SH ; E. Sh. EL-Sokkary ; M. E. Abdel-Aziz and M. M. M. Refaey.

Dairy department, Faculty of agriculture Mansoura University, EGYPT.

\begin{abstract}
Ricotta cheese was made from acidified skim milk by yogurt starter at $\mathrm{pH}$ 5.8- 5.9 and adding different concentration of skim milk powder and milk protein concentrate. Acidity ,Fat, Protein, Ash, Total solids and the yield\% of cheese were increased with increasing of skim milk powder and milk prote in concentrate while $\mathrm{pH}$ values were decreased. The cheese made by yoghurt starter coagulant with adding $2 \%$ skim milk powder had a higher values for the rheological properties Hardness, adhesiveness, Cohesiveness (g), Springiness $(\mathrm{mm})$, Gumminess $(\mathrm{g})$ and Chewiness $(\mathrm{g} . \mathrm{mm})$ which were $5777(\mathrm{~g}), 4318.9(\mathrm{~g}), 0.56(\mathrm{~g}), 9.34(\mathrm{~mm}), 2656(\mathrm{~g})$ and 24820.28 (g.mm) respectively, while aading $4 \%$ skim milk powder had the lowest rheological properties for Hardness and adhesiveness which were $(2712(\mathrm{~g})-3391.8(\mathrm{~g})$ respectively .The rheological properties in treatment (6\% skim milk powder) as follows, Cohesiveness (g),Springiness $(\mathrm{mm})$, Gumminess $(\mathrm{g})$ and Chewiness $(\mathrm{g} . \mathrm{mm})$ were $0.45(\mathrm{~g}), 7.81(\mathrm{~mm}), 1219(\mathrm{~g})$ and $9520.01(\mathrm{~g} . \mathrm{mm})$ respectively. On the other hand, Ricotta cheese made by yoghurt starter coagulant with $4 \%$ milk protein concentrate powder showed the highest properties .Hardness $(\mathrm{g})$, Cohesiveness (g), Springiness (g), Gumminess(g) and Chewiness (g.mm) were 6119(g),0.62(g),10.63(mm),3778(g) and 43466.59 (g.mm), respectively while, adding $6 \%$ milk protein concentrate powder gave the highest value for adhesiveness [4127.91(g)] .but the same treatment had the lowest value for the Hardness(g), Cohesiveness (g), Springiness $(\mathrm{mm}), \quad$ Gumminess $(\mathrm{g})$ and Chewiness $(\mathrm{g} . \mathrm{mm})$ values being $4377(\mathrm{~g}), 0.39(\mathrm{~g}), 7.95 \mathrm{~mm}, 1709 \mathrm{~g}$ )and $13595 \mathrm{~g} . \mathrm{mm}$,respectively. The microbiological tests showed that, the control samples contained the lowest of total bacterial counts $\left(7 \times 10^{4} \mathrm{cfu} / \mathrm{g}\right)$, protolytic bacteria $\left(6 \times 10^{3} \mathrm{cfu} / \mathrm{g}\right)$ and lipolytic bacteria $\left(1 \times 10^{3} \mathrm{cfu} / \mathrm{g}\right)$, All samples were free from coliform bacteria and staphylococcus. spp. Addition of $2 \%$ skim milk powder and milk protein concentrate showed the highest total score points for Sensory evaluation ( 83.5 and $82.8 \%$ )., adding 6\% skim milk powder and milk protein concentrate showed the lowest total score points for Sensory evaluation (77.8 and $78.8 \%$ ).Generally , this work was carried out to study the effect of use skim milk and milk protein concentrate by different percent on the composition and the quality of Ricotta cheese.
\end{abstract}

Keywords: Ricotta cheese- skim milk - milk protein concentration

\section{INTRODUCTION}

The consumption and manufacture of cheese is increasing worldwide at a rate of about $2 \%$ per year. As a result, the amount of cheese whey is also increased and is estimated to be about 130 million tons annually (Korhonen et al., 1998). Ricotta cheese is a high moisture soft cheese (Modler and Emmons, 2001). It can be produced using cheese whey or milk, or a mixture of both (Pizzillo et al., 2005). Ricotta cheese is very mild and it is 
used in many Italian dishes. Several methods have been developed for utilization of whey. Fresh Ricotta cheese had a mild and mutty Flavour and is used as a Flavour enhance in Salad (Kosikowski, 1982). Several methods have been suggested for Ricotta cheese making. ( Weather up, 1986 and Modler \& Emmons, 1994). These include study the effect of type of acidulant on the quality of Ricotta cheese. Production of Ricotta cheese has been considered to be one of the economical ways for the utilization of whey. So, the manufacture of Ricotta cheese could easily be undertaken as an additional source of income (shukla et al., 1986). Therefore, this work was carried out to study the effect of use skim milk and milk protein concentrate on the composition and the quality of Ricotta cheese.

\section{MATERIALS AND METHODS}

Skim milk was obtained from Dairy Department, Faculty of Agriculture, Mansoura University having the following composition in the Table (1) .

Table (1) Chemical composition of skim milk

\begin{tabular}{|l|c|c|c|c|}
\hline TS\% & TP\% & FAT\% & Lactose $\%$ & pH value \\
\hline 9.38 & 3.47 & 0.45 & 5.0 & 6.57 \\
\hline
\end{tabular}

Yoghurt starter ( streptococcus thermophillus and ,lactobacillus delbrukii subsp bulgaricus) were obtained from ch Hansen's Laboratories Denemark and were added at $40{ }^{\circ} \mathrm{C}$.

Skim milk powder was obtained from local Company having the follows composition as shown in Table (2)

Table (2) chemical composition of skim milk powder.

\begin{tabular}{|l|c|}
\hline Components & Percentages \\
\hline Moisture\% & 2.75 \\
\hline T.P\% & 36 \\
\hline Lactose\% & 52 \\
\hline Fat $\%$ & 1.25 \\
\hline Ash $\%$ & 8 \\
\hline
\end{tabular}

Milk protein concentrate powder was obtained from local Company having the follows composition as shown in Table (3)

Table (3) chemical composition of milk protein concentration

\begin{tabular}{|l|c|}
\hline Components & Percentage \\
\hline Moisture\% & 4.4 \\
\hline T.P\% & 69.8 \\
\hline Lactose\% & 17.2 \\
\hline Fat\% & 1.4 \\
\hline Ash\% & 7.2 \\
\hline
\end{tabular}

Ricotta cheese was made as recommended by (Scott, 1981) with some modification as follows:

1- Standardization of fresh skim milk.

2- Acidified fresh milk of all treatments to $\mathrm{pH}$ 5.8-5.9 by adding yoghurt starter culture. 
3- Adding of the skim milk powder and milk protein concentrate powder with ratios of $2 \%, 4 \%$ and $6 \%$.

4- Heating of the milk of all treatments to $80^{\circ} \mathrm{C}$ with stirring to produce flakes of curd in clear whey.

5- Scooping the curd from the surface of the clear whey into perforated tinned steel containers lined with open weave cloth.

6- Cooling the filled containers in cold water then covering with calico and putting crushed ice on the top.

7- Salt was added $(0.5 \%)$ in milk and the all samples were stored in the refrigerator $4 \pm 1^{0} \mathrm{C}$.

1- Chemical analysis: acidity, fat, total protein, ash and Total solids were determined according to Ling (1963) .pH value were measured using laboratory $\mathrm{pH}$ meter with glass electrodes $\mathrm{pH}$-meter Jan way $3010-$ England

2- Rheological properties of cheese: The texture properties of cheese samples were evaluated using (Texture analyzer by (CNS / FARNELLFRA, Borechamwoad, Hertfordsimre, England). Control and experimental cheese samples were taken from fresh cheeses and 21 days of storage, then were measured immediately. Cheese sample size was $30 \mathrm{~mm}$ of diameter and $20 \mathrm{~mm}$ of high. Speed was $1 \mathrm{~mm} / \mathrm{s}$ and 10 $\mathrm{mm}$ was the distance of penetration. Samples were allowed to stand at ambient temperature for at least $20 \mathrm{~min}$ prior testing. The probe used was $\mathrm{TA} 15-45^{\circ} \mathrm{C}$ perplex cone. Data were collected on computer and the texture profile parameters were calculated from LFRA texture analyzer and computer interface.

The following texture profile parameters were obtained and calculated as describe by Bourne (1978):

i) The compressive force $(\mathrm{g})$ recorded at maximum compressive during in the first bite as a measure of Hardness

ii) The ratio of the positive force area under the curve during the second compression (bite) to that during the first compression (a2/a1) as a measure of cohesiveness.

iii) The height $(\mathrm{mm})$ to which the sample recovered during the time that clasped between the end of the first bite the start of the second bite, as a measure of Springiness.

iV)The product of hardness $X$ Cohesiveness $(\mathrm{g})$, as a measure of gumminess.

V) The product of gumminess $X$ springiness (g.mm), as a measure of chewiness.

Vi) The modulus (the slope of force, representative of sample rigidity).

3- Microbiological test: Total bacterial counts were determined using the melted media (Difco1971). Lipolytic bacterial count and Proteolytic bacterial count were carried out as described by Chalmers (1962) .Coliform bacteria were counted by using Macconky broth. Staphylococcus sp. was counted by using staphylococcus medium 110. The plates were incubated at $37^{\circ} \mathrm{C}$ for $24-36 \mathrm{hrs}$ and examined for orange colonies. 
4- Organoleptic properties of cheese: Ten trained panelists from the staff members of the Dairy Department of Faculty of Agriculture, Mansoura University evaluated of each cheese sample and used a quality rating score card for evaluation of flavor, body and texture, appearance were $40 \%, 30 \%$ and $30 \%$ respectively according to Hassan (1996)

\section{RESULTS AND DISCUSSION}

\section{Chemical properties}

1- Acidity and $\mathrm{pH}$ values in Table(4), show that little difference were occurred in acidity and $\mathrm{pH}$ value of cheese in the different treatments .At the same time, the acidity were decreased and increased in $\mathrm{pH}$ values had the opposite trend by increasing concentration of milk protein concentrate and skim milk powder. Also, it was observed that the addition of $2 \%$ milk protein concentrate caused more increasing in acidity and decreasing in $\mathrm{pH}$ values The same was observed with the same properties of skim milk powder during the storage period in $\mathrm{pH}$ values were detected during storage. Also, the addition of $6 \%$ milk protein concentrate resulted in the highest acidity and the lowest $\mathrm{pH}$ value.

2- Fat content It can be seen from Table (4), that the increase of skim milk powder and milk protein concentrate resulted in an increase in fat content. While, the addition of $2 \%$ caused more increase in the fat content of milk protein concentrate when compared with the same percent of skim milk powder. The same effect was observed among other percentage of addition of skim milk powder and milk protein concentrate powders. Also, the addition of $6 \%$ milk protein concentrate caused a highest fat content when compared with the same level of skim milk powder. It was observed the highest rate of increase when $2 \%$ milk protein concentrate was added

3- Total protein (T.P) As shown in Table (4) Increasing of the percentage of added milk protein concentrate caused on increase in T.P \% comparing with the skim milk powder in different concentration

4- Ash content Table (4), showed that the addition of $2 \%$ milk protein concentrate resulted more increase in ash content when compared with the same level of skim milk powder. The same effect was observed if more addition of skim milk and milk protein concentrate powder were used. Also, it was observed that addition of $6 \%$ percent of milk protein concentrate had the highest ash content compared with same percent of skim milk powder.

5- Total solids (T.S) in Table (4), showed that, in general, the increasing of skim milk powder and milk protein concentrate addition caused an increase in total solids contents, Also, it was observed addition of 2,4, 6 $\%$ milk protein concentrate caused the highest total solid content, compared with 2, 4 and $6 \%$ skim milk powder

6- Cheese yield Data in Table(4), indicates that the yield of Ricotta cheese made using skim milk with acidification by yoghurt starter with the addition of different levels of skim milk powder and milk protein 
concentrate powder (2, 4 and 6\%). It can be, seen that the addition of 2 $\%$ milk protein concentrate caused the highest cheese yield,. The Ricotta cheese made by skim milk with acidification by yoghurt starter with addition of different concentration of skim milk powder and milk protein concentrate powder $(2,4$ and $6 \%$ ) had the highest yield compared with the Ricotta cheese made by skim milk with acidification by phosphoric acid with addition of different levels of skim milk powder and milk protein concentrate powder $(2,4$ and $6 \%)$.

Table (4): Effect of addition of different concentration of skim milk powder and milk protein concentrates powder on chemical properties of Ricotta cheese:

\begin{tabular}{|c|c|c|c|c|c|c|c|c|}
\hline \multirow{3}{*}{ Test } & \multirow{3}{*}{$\begin{array}{c}\text { Storage } \\
\text { Period } \\
\text { (days) }\end{array}$} & \multicolumn{7}{|c|}{ Treatments } \\
\hline & & \multirow{2}{*}{ control } & \multicolumn{3}{|c|}{ skim milk powder \% } & \multicolumn{3}{|c|}{$\begin{array}{c}\text { milk protein } \\
\text { concentrate } \%\end{array}$} \\
\hline & & & $2 \%$ & $4 \%$ & $6 \%$ & $2 \%$ & $4 \%$ & $6 \%$ \\
\hline \multirow{4}{*}{ Acidity\% } & Fresh & 0.23 & 0.37 & 0.42 & 0.55 & 0.29 & 0.36 & 0.51 \\
\hline & 7 & 0.24 & 0.39 & 0.45 & 0.58 & 0.32 & 0.38 & 0.54 \\
\hline & 14 & 0.26 & 0.45 & 0.48 & 0.61 & 0.35 & 0.42 & 0.68 \\
\hline & 21 & 0.29 & 0.51 & 0.52 & 0.68 & 0.38 & 0.45 & 0.72 \\
\hline \multirow{4}{*}{$\begin{array}{l}\mathrm{pH} \\
\text { values }\end{array}$} & Fresh & 5.09 & 4.78 & 4.62 & 4.55 & 4.95 & 4.82 & 4.61 \\
\hline & 7 & 4.96 & 4.65 & 4.56 & 4.51 & 4.80 & 4.75 & 4.58 \\
\hline & 14 & 4.90 & 4.61 & 4.50 & 4.46 & 4.75 & 4.66 & 4.51 \\
\hline & 21 & 4.85 & 4.58 & 4.43 & 4.39 & 4.68 & 4.58 & 4.35 \\
\hline \multirow{4}{*}{ FAT\% } & Fresh & 2.00 & 2.50 & 2.63 & 2.75 & 3.00 & 3.20 & 3.35 \\
\hline & 7 & 2.15 & 2.55 & 2.68 & 2.82 & 3.25 & 3.45 & 3.55 \\
\hline & 14 & 2.25 & 2.61 & 2.76 & 2.85 & 3.31 & 3.66 & 3.71 \\
\hline & 21 & 2.30 & 2.67 & 2.81 & 2.90 & 3.50 & 3.75 & 3.80 \\
\hline \multirow{4}{*}{ TP\% } & Fresh & 24.15 & 26.97 & 29.10 & 31.71 & 29.55 & 31.80 & 33.55 \\
\hline & 7 & 24.44 & 27.50 & 29.83 & 31.85 & 29.78 & 31.95 & 33.74 \\
\hline & 14 & 24.61 & 28.28 & 30.54 & 31.96 & 30.85 & 32.10 & 33.89 \\
\hline & 21 & 25.02 & 28.71 & 30.76 & 32.12 & 30.95 & 32.42 & 34.14 \\
\hline \multirow{4}{*}{ Ash\% } & Fresh & 1.98 & 2.672 & 2.753 & 2.842 & 2.568 & 2.655 & 2.985 \\
\hline & 7 & 2.06 & 2.714 & 2.798 & 2.924 & 2.650 & 2.823 & 3.115 \\
\hline & 14 & 2.13 & 2.842 & 2.815 & 3.012 & 2.751 & 2.915 & 3.235 \\
\hline & 21 & 2.21 & 2.867 & 2.995 & 3.150 & 2.840 & 3.125 & 3.355 \\
\hline \multirow{4}{*}{ TS\% } & Fresh & 30.15 & 33.50 & 37.40 & 39.30 & 35.35 & 39.30 & 41.30 \\
\hline & 7 & 30.45 & 33.97 & 37.76 & 39.53 & 35.90 & 39.95 & 41.65 \\
\hline & 14 & 30.86 & 34.25 & 38.12 & 40.76 & 36.15 & 40.20 & 42.42 \\
\hline & 21 & 31.01 & 34.58 & 38.34 & 40.98 & 36.70 & 40.65 & 42.95 \\
\hline Yield\% & & 17.5 & 23.0 & 30 & 34.3 & 24 & 32 & 35 \\
\hline
\end{tabular}

Rheological properties of cheese: The changes in texture primary parameters (hardness, adhesiveness, cohesiveness, and springiness) and texture secondary parameters (Gumminess and Chewiness) of Ricotta cheeses made from skim milk and coagulated with yoghurt starter at zero time of manufacture and after 21 days storage are shown in 
Table(5).Hardness at zero time of manufacture, the fresh cheese made using $4 \%$ skim milk powder showed lower hardness than other treatments either fresh cheese or during storage periods, while the highest values of hardness were found in cheeses made using $2 \%$ skim milk powder either fresh cheese and $4 \%$ milk protein concentrate during storage periods . Cheese made using $4 \%$ skim milk powder recorded little higher hardness than that made by using Yoghurt starter only but cheese made by using yoghurt starter recoded higher hardness than that made by using 2 and $6 \%$ skim milk powder at 21 day. There was little difference in hardness between cheese made with 4 and $6 \%$ skim milk powder. The results indicates that the addition of $2 \%$ skim milk powder or $2 \%$ milk protein concentrate increased the hardness of Ricotta cheese, while the addition of $6 \%$ of skim milk powder or milk protein concentrate decreased the hardness in ricotta cheese. this is related mostly to the high level of dry matter and protein content in cheeses made using $2 \%$ skim milk powder or milk protein concentrate comparing with cheese made without addition. The dry matter and protein contents were higher in $6 \%$ skim milk powder and milk protein concentrate, while the hardness was lower than that in cheese made without addition. This may be attributed to the breakdown of the texture and body by increasing the dry matter and protein level of Ricotta cheese, but is not in other rennet coagulated cheese. Our results are in parent with those obtained by (Awad, S; 2011)Hardness decreased consistently during 21 days of storage. The decrease in hardness during the 21 days of storage was related to decreasing moisture content which acts as a plasticizer in the protein matrix, thereby making it less elastic and more susceptible to fracture upon compression this agree with data obtained by (Fox et al., 2000). A reduction in hardness at 21 days of storage has been noticed in all cheese. The decrease in hardness after storage is due to the initial rubbery texture of cheese, which rapidly transforms into a smoother, and more soft product due to attributed to a number of factors: (1) proteolysis of casein network,; (2) increasing the protein hydration as the moisture content decreased at 21 days of storage comparing to that at $1^{\text {st }}$ day of manufacturing. The proteins in cheese are highly hydrated and even buried water molecules in globular proteins can exchange with bulk solvent on a nanosecond to microsecond timescale and the protein matrix absorbed the water originally located in the fat-serum channels as mentioned by (Donald et al., 1999; Guinee (2002) Lucey et al., 2003); and (3) solubilization of CCP in cheese as the soluble calcium increased during acidification and storage. During cheeses storage, the solubilization of CCP resulted in a weaker association between casein molecules, which decrease the cheese rigidity (Lucey et al., 2003).

Adhesiveness As shown in Table(5) The adhesiveness was higher in cheese made with addition 6\% skim milk powder than that in all cheeses made by using skim milk powder or milk protein concentrate . It was noticed that the cheeses made using skim milk powder had higher adhesiveness values than that made using milk protein concentrate, and there were a positive or negative correlation between increasing the level of skim milk powder or milk protein concentrate and adhesiveness. After 21 days of storage, the adhesiveness reduced in all cheeses except the cheese made 
with $2 \%$ skim milk powder, which recorded high level of adhesiveness after 21 days when compared with fresh Table (5).

Cohesiveness Also it can be seen from the same table that. there was no marked difference in cohesiveness among cheese made with different concentration of skim milk powder or milk protein concentrate at fresh and 21days of storage, while the cohesiveness is higher in cheese made without addition, while all cheese made from skim milk powder or milk protein concentrate received lower cohesiveness values compared with cheese made without addition. The cohesiveness values did not change after 21 days comparing with fresh cheese of manufacture.

Table (5): Effect of addition of different concentration of skim milk powder and milk protein concentrates powder on Rheological properties of Ricotta cheese.

\begin{tabular}{|c|c|c|c|c|c|c|c|c|}
\hline \multirow{3}{*}{ Components } & \multirow{3}{*}{$\begin{array}{c}\text { Storage } \\
\text { Period } \\
\text { (days) }\end{array}$} & \multicolumn{7}{|c|}{ Treatments } \\
\hline & & \multirow{2}{*}{ control } & \multicolumn{3}{|c|}{ skim milk powder \% } & \multicolumn{3}{|c|}{$\begin{array}{l}\text { milk protein } \\
\text { concentrate \% }\end{array}$} \\
\hline & & & $2 \%$ & $4 \%$ & $6 \%$ & $2 \%$ & $4 \%$ & $6 \%$ \\
\hline \multirow{2}{*}{ Hardness (g) } & Fresh & 5119 & 5777 & 2712 & 2738 & 5351 & 6119 & 4377 \\
\hline & 21 & 2000 & 1548 & 1236 & 1525 & 2662 & 4317 & 3229 \\
\hline \multirow{2}{*}{$\begin{array}{l}\text { Adhesiveness } \\
\text { (g) }\end{array}$} & Fresh & 764.05 & 4318.9 & 3391.8 & 4924 & 2878 & 2867 & 4127. \\
\hline & 21 & \begin{tabular}{|l|}
744.43 \\
\end{tabular} & 2699.0 & 2053.96 & 2695 & 1551 & 1489 & 2344.8 \\
\hline \multirow{2}{*}{$\begin{array}{l}\text { Cohesiveness } \\
\text { (g) }\end{array}$} & Fresh & 0.74 & 0.56 & 0.49 & 0.45 & 0.61 & 0.62 & 0.39 \\
\hline & 21 & 0.71 & 0.53 & 0.50 & 0.46 & 0.62 & 0.63 & 0.49 \\
\hline \multirow{2}{*}{$\begin{array}{l}\text { Springiness } \\
(\mathrm{mm})\end{array}$} & Fresh & 11.42 & 9.34 & 8.25 & 7.81 & 10.63 & 10.63 & 7.95 \\
\hline & 21 & 8.39 & 6.72 & 5.82 & 5.84 & 7.84 & 11.53 & 7.38 \\
\hline \multirow{2}{*}{$\begin{array}{l}\text { Gumminess } \\
(\mathrm{g})\end{array}$} & Fresh & 3793 & 2656 & 1323 & 1219 & 3265 & 3778 & 1709 \\
\hline & 21 & 1420 & 664 & 621 & 701 & 1623 & 2718 & 1581 \\
\hline \multirow{2}{*}{$\begin{array}{l}\text { Chewiness } \\
\text { (g.mm) }\end{array}$} & Fresh & 43336 & 24820 & 10912.42 & 9520 & 34697 & 43466 & 13595 \\
\hline & 21 & 11921 & 4464 & 3615.46 & 4094 & 12723 & 31347 & 11666 \\
\hline
\end{tabular}

Springiness in Table (5).shows the effect of supplemented milk to made Ricotta cheese by skim milk powder and milk protein concentrate on Springiness values. The Springiness at fresh and 21 days of storage was lower in cheeses made using milk supplemented by skim milk powder and milk protein concentrate when comparing with control. However, increasing the percentage of skim milk powder or milk protein concentrate decreased the springiness value as compared to control cheeses. However, springiness reduced after 21 days of storage in all samples made with different concentration of skim milk powder, milk protein concentrate and control. It may be attributed to the release of calcium ions from mono-calcium and dicalcium Para K-caseinate molecules. These molecules have been reported to be responsible for the springiness of cheese curd (Kanawjia, et al., 1995).

Gumminess is the energy required to disintegrate a semisolid food for swallowing. In general, the trend of gumminess values was comparable with hardness at $1^{\text {st }}$ day of manufacturing (Table 5). Gumminess values were decreased by increasing the levels of skim milk powder or milk protein concentrate except in $4 \%$ protein concentrate when compared to control cheese. The lower gumminess values were in cheeses made using $6 \%$ skim 
milk powder or milk protein concentrate when compared to that made using $2 \%$ skim milk powder or milk protein concentrate The gumminess decreased in all cheeses at 21 days of storage comparing to that at $1^{\text {st }}$ days of storage.

Chewiness is the energy required to chew a solid food product to a state where it is ready for swallowing. The chewiness values were well compared with Gumminess values in all cheese (Table 5). As chewiness values decreased by increasing the levels of skim milk powder or milk protein concentrate when compared to control cheese. The lower Chewiness values were in cheese made by using $6 \%$ skim milk powder or milk protein concentrate when compared to that made using $2 \%$ skim milk powder or milk protein concentrate. There was a correlation between cheese hardness and chewiness, harder cheese is more difficult to chew (Beal and Mittal, 2000).

Table (6): Effect of addition of different concentration of skim milk powder and milk protein concentrate powder on microbiological properties of Ricotta cheese.

\begin{tabular}{|c|c|c|c|c|c|c|c|c|}
\hline \multirow{3}{*}{$\begin{array}{l}\text { microbiological } \\
\text { properties }\end{array}$} & \multirow{3}{*}{$\begin{array}{c}\text { Storage } \\
\text { Period } \\
\text { (days) }\end{array}$} & \multicolumn{7}{|c|}{ Treatments } \\
\hline & & \multirow{2}{*}{ control } & \multicolumn{3}{|c|}{ skim milk powder $\%$} & \multicolumn{3}{|c|}{$\begin{array}{l}\text { milk protein } \\
\text { concentrate \% }\end{array}$} \\
\hline & & & $2 \%$ & $4 \%$ & $6 \%$ & $2 \%$ & $4 \%$ & $6 \%$ \\
\hline \multirow{4}{*}{$\begin{array}{l}\text { TCx10 } \\
\mathrm{cfu} / \mathrm{g}\end{array}$} & Fresh & 7.0 & 9.0 & 14.0 & 17.0 & 12.0 & 15.0 & 18.0 \\
\hline & 7 & 9.0 & 11.0 & 15.0 & 20.0 & 16.0 & 18.0 & 22.0 \\
\hline & 14 & 15.0 & 20.0 & 27.0 & 31.0 & 21.0 & 29.0 & 32.0 \\
\hline & 21 & 22.0 & 26.0 & 31.0 & 34.0 & 29.0 & 35.0 & 37.0 \\
\hline \multirow{4}{*}{$\begin{array}{l}\text { Pr. b } \times 10^{3} \\
\mathrm{cfu} / \mathrm{g}\end{array}$} & Fresh & 6.0 & 7.0 & 10.0 & 14.0 & 8.0 & 12.0 & 15.0 \\
\hline & 7 & 8.0 & 10.0 & 13.0 & 16.0 & 12.0 & 15.0 & 17.0 \\
\hline & 14 & 11.0 & 13.0 & 17.0 & 21.0 & 14.0 & 19.0 & 23.0 \\
\hline & 21 & 14.0 & 16.0 & 20.0 & 31.0 & 15.0 & 22.0 & 27.0 \\
\hline \multirow{4}{*}{ Ly.b $\times 10^{3}$ c.f.u/g } & Fresh & 1.0 & 3.0 & 4.0 & 6.0 & 4.0 & 5.0 & 8.0 \\
\hline & 7 & 2.0 & 4.0 & 7.0 & 8.0 & 5.0 & 8.0 & 10.0 \\
\hline & 14 & 5.0 & 6.0 & 9.0 & 12.0 & 8.0 & 11.0 & 13.0 \\
\hline & 21 & 7.0 & 9.0 & 11.0 & 14.0 & 12.0 & 15.0 & 18.0 \\
\hline \multirow{4}{*}{$\begin{array}{l}\text { Coliform( E.coli) \& } \\
\text { Staphylococcus sp } \\
\text { bacteria } \times 10^{3} \\
\text { c.f.u/g }\end{array}$} & Fresh & ND & ND & ND & ND & ND & ND & ND \\
\hline & 7 & ND & ND & ND & ND & ND & ND & ND \\
\hline & 14 & ND & ND & ND & ND & ND & ND & ND \\
\hline & 21 & ND & ND & ND & ND & ND & ND & ND \\
\hline
\end{tabular}

T.C.: total bacterial count Pro. b: proteolytic bacterial counts

Ly. b: lipolytic bacterial counts CFU: colony forming unit N.D: not detectives

Microbiological tests of Ricotta cheese made by the addition of different concentration of skim milk or milk protein concentrate powder ,it can be seen from the results in Table(6) that the control cheese had the lowest total bacterial count compared with other treatments,. While the addition of $2 \%$ skim milk powder or milk protein concentrate had the lower total count of bacteria Compared with different concentration of skim milk powder or milk protein concentrate powder. Also, cheese control made by acidification using yoghurt starter had the lower Proteolytic, lipolytic bacterial counts compared with other treatment, either when addition skim milk 
powder or milk protein concentrate. Addition of $2 \%$ skim milk powder had the lowest Proteolytic and lipolytic bacterial count compared with the same percent of milk protein concentrate. The same effects were observed among other percent addition skim milk powder and milk protein concentrate, either fresh cheese or during storage periods. Generally, cheese from different treatments were free from coliform (E. coli) and Staphylococcus $s p$. The same effects were observed among other percent addition skim milk powder and milk protein concentrate.

Organoleptic properties Table( 7 ), shows that the Ricotta cheese made by the addition of $2 \%$ skim milk powder and $2 \%$ milk protein concentrate had the highest total score points, compared with the other levels and control either fresh or during storage periods.

Table (7): Effect of addition of different concentration of skim milk powder and milk protein concentrate powder on organoleptic properties of Ricotta cheese

\begin{tabular}{|c|c|c|c|c|c|c|c|c|}
\hline \multirow{3}{*}{ Properties } & \multirow{3}{*}{$\begin{array}{c}\text { Storage } \\
\text { Period } \\
\text { (days) }\end{array}$} & \multicolumn{7}{|c|}{ Treatments } \\
\hline & & \multirow{2}{*}{ control } & \multicolumn{3}{|c|}{ skim milk powder $\%$} & \multicolumn{3}{|c|}{$\begin{array}{l}\text { milk protein } \\
\text { concentrate \% }\end{array}$} \\
\hline & & & $2 \%$ & $4 \%$ & $6 \%$ & $2 \%$ & $4 \%$ & $6 \%$ \\
\hline \multirow{4}{*}{$\begin{array}{l}\text { Flavour } \\
(40)\end{array}$} & Fresh & 34.0 & 35.0 & 34.0 & 34.0 & 34.5 & 34.0 & 33.0 \\
\hline & 7 & 34.5 & 35.5 & 34.0 & 33.5 & 34.5 & 34.2 & 33.3 \\
\hline & 14 & 33.0 & 34.8 & 34.4 & 31.0 & 33.7 & 34.0 & 32.0 \\
\hline & 21 & 33.0 & 33.5 & 33.0 & 30.0 & 33.2 & 33.0 & 31.0 \\
\hline \multirow{4}{*}{$\begin{array}{l}\text { Body \& } \\
\text { Texture } \\
(30)\end{array}$} & Fresh & 24.5 & 26.0 & 25.0 & 25.0 & 25.5 & 24.5 & 25.0 \\
\hline & 7 & 26.0 & 26.5 & 24.2 & 25.3 & 26.0 & 24.9 & 25.3 \\
\hline & 14 & 24.0 & 25.8 & 24.5 & 25.0 & 25.8 & 24.5 & 25.0 \\
\hline & 21 & 23.5 & 24.0 & 24.0 & 24.0 & 25.0 & 24.0 & 24.3 \\
\hline \multirow{4}{*}{$\begin{array}{l}\text { Appearance } \\
(30)\end{array}$} & Fresh & 25.4 & 26.0 & 24.0 & 24.0 & 26.0 & 25.0 & 24.0 \\
\hline & 7 & 25.7 & 26.4 & 24.6 & 24.5 & 26.4 & 25.3 & 24.2 \\
\hline & 14 & 26.0 & 26.1 & 24.2 & 24.2 & 26.0 & 24.5 & 24.0 \\
\hline & 21 & 25.5 & 25.3 & 24.0 & 23.8 & 25.3 & 24.5 & 23.5 \\
\hline \multirow{4}{*}{$\begin{array}{l}\text { Total } \\
(100)\end{array}$} & Fresh & 83.9 & 87.0 & 83.0 & 83.0 & 86.0 & 83.5 & 82.0 \\
\hline & 7 & 86.2 & 88.4 & 83.8 & 83.3 & 86.9 & 84.2 & 82.8 \\
\hline & 14 & 83.0 & 86.7 & 83.1 & 80.2 & 85.5 & 83.0 & 81.0 \\
\hline & 21 & 82.0 & 82.8 & 81.0 & 77.8 & 83.5 & 81.5 & 78.8 \\
\hline
\end{tabular}

\section{REFERENCES}

Awad, S (2011). Texture and Microstructure: in Practical Food and Research pp. 361-391 (ed. Rui M. S. Cru), Nova Science publishers, Inc.Bourne, M. 1978. Texture Profile Analysis. Food Technol. 32:62-66, 72.

Beal, P., and G. S. Mittal. 2000. Vibration and compression responses of Cheddar cheese at different fat content and age. Milchwissenschaft 55:139-142.

Bourne, M. (1978). Texture Profile Analysis. Food Tech. 32: 62-72.

Chalmers, C. H.(1962): Bacteria in relation to the milk supply. 4th Ed. Edward Annold, London 
Difco Manual ( 1971 ) Dehydrated Culture Media and Reagent for Microbiological Clinical Laboratory Procedures.

Donald, D.B., J. Syrgiannis, F. Hunter, G. Weiss. 1999. Agricultural pesticides threaten the ecological integrity of northern prairie wetlands. Sci. Total Environ. 231: 173-181.

Fox. P.E.Guinee, T. P. Cogen . T .M. and Mcsweeney , P.L.,H (2000). Fundmentals of cheese science .Aspen Publish -ers.Gaithersburg .MD.

Guinee, T. P. 2002. Cheese Rheology. Pages 341-349 in Encyclopedia of Dairy Science. H. Roginski, J. W. Fuquay, and P. F. Fox, ed. Academic Press, London, UK.

Hassan,M.N.A. (1996). Cardamon and Mastiche oils as natural preservatives of butter. Dairy Dept. Fac. of Agric. Cairo Univ., Egypt.

Ling, E. R. (1963). A textbook of Dairy Chemistry. Chapman and Hall Ltd. 37 Esser Street V.C.2.Practical 1963. 4th Edition .London.

Lucey, J. A., Johnson, M. E., and Home , D.S.(2003).perspectives on the basis of the rheology and texture properties of cheese .J. Dairy sci.86:2725-2743

Kanawjia, S. K., P. Rajesh, L. Sabikhi, and S. Singh. (1995). Flavor, chemical and texture profile changes in accelerated ripened Gouda cheese. Lebensm. Wiss. Technol. 28:577-583.

Kosikowski, F.V. (1982). Cheese and fermented milk food. Edwards Brothers.Inc.,Ann.,Arbor,Michigan,U.S.A.

Korhonen, H. ; Anne Pihlanto-Leppalo ;Pirjo Rantamali and Tuomo Tupusela(1998). The functional and biological properties of whey proteins: Prospects for the development of functional fooods. Agricultural and Food Science in Finland. Vol.7(8): 283-296.

Modler, H. W.; Emmons, D. B.(1994). Yield of cheese-base material produced by application of continuous Ricotta processing technology. Cheese yield and factors affecting its control. International Dairy Federation, Brussels, Belgium: 1994. 424-432.

Modler, H.W. and Emmons, D.B. (2001). The use of continuous Ricotta cheese processing to reduce ingredient cost in further procesed cheese products. International Dairy Journal 11:517-523

Pizzillo, M.; Claps, S.; Cifunj, G.F.; Fedele, V. and Rubion, R. (2005). Effect of goat breed on the sensory, chemical and nutritional characteristics of Ricotta cheeseLiverstock Production Science94: 33-40.

Scott, R. (1981). Cheese making practice, Applied Sci. Publishers LTD, N. Y. pp. 361-383.

Shukla, F.C. and Manhlt Kaur Brar (1986). Manufacture and signification of Ricott cheese.Indian J.Dairy Sci., 39: (4): 343.

Weatherup, W. (1986). The effect of processing variables on the yield and quality of Ricotta cheese. Dairy Industries, International, 51:42 . 


\section{تأثثير تدعيم جبن الريكوتـا بـاللبن الفرز المجفف ومركز بروتين اللبن علي جودة الجبن الناتج اثناء التخزين الرين

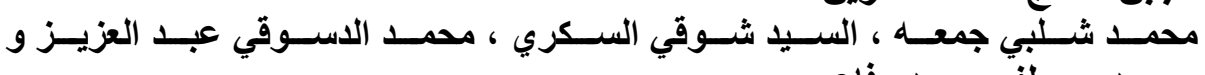

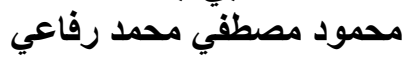 قسم الالبان ـ كلية الزراعة - جامعة المنصورة ـ مصر}

تم تصنيع جبن الريكوتا من اللبن الفرز بواسطة التجبن الحراري الحمضي باستخدام بادئ

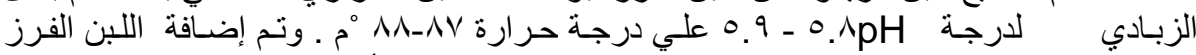

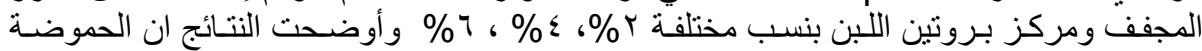

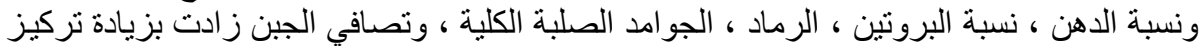

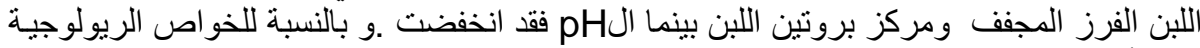

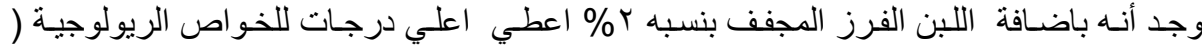

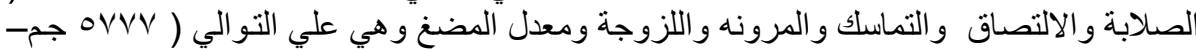

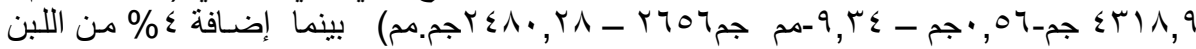

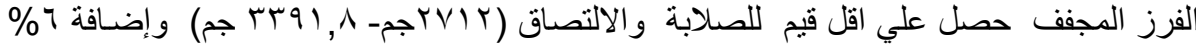

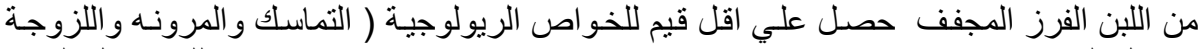

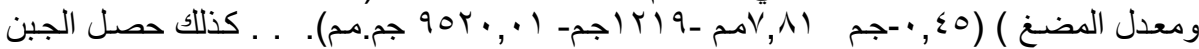

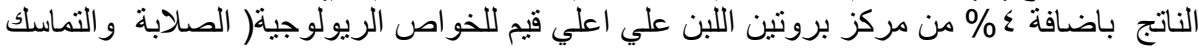

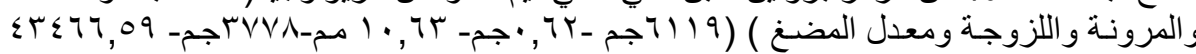

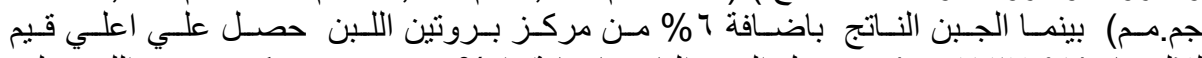

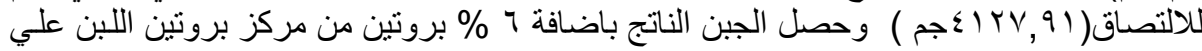

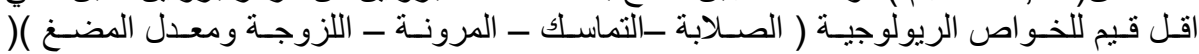
الم

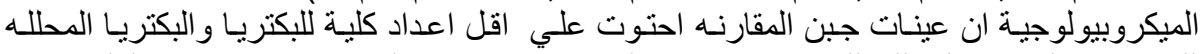

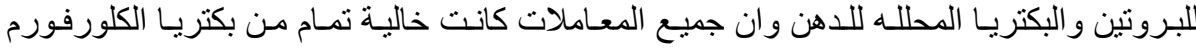

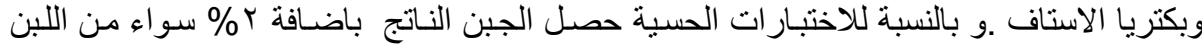

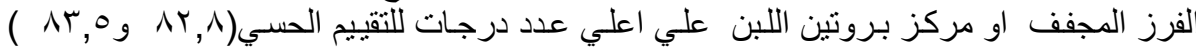

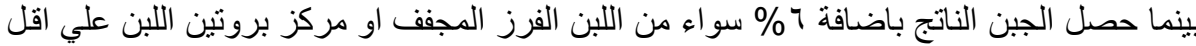

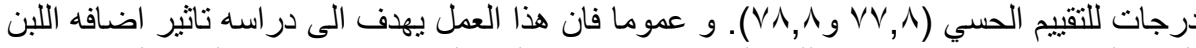

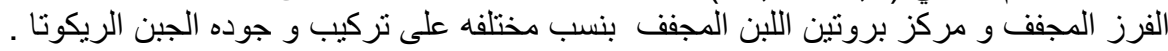

